\title{
Nanoencapsulation of Polyphenols towards Dairy Beverage Incorporation
}

\author{
Sara Silva, Mariana Veiga, Eduardo M. Costa, Ana L. S. Oliveira, Ana Raquel Madureira \\ and Manuela Pintado * \\ Centro de Biotecnologia e Química Fina-Laboratório Associado, Escola Superior de Biotecnologia, \\ Universidade Católica Portuguesa/Porto, Rua Arquiteto Lobão Vital, 4202-401 Porto, Portugal; \\ snsilva@porto.ucp.pt (S.S.); mveiga@porto.ucp.pt (M.V.); emcosta@porto.ucp.pt (E.M.C.); \\ asoliveira@porto.ucp.pt (A.L.S.O.); rmadureira@porto.ucp.pt (A.R.M.) \\ * Correspondence: mpintado@porto.ucp.pt; Tel.: +351-225-580-001
}

Received: 11 June 2018; Accepted: 7 August 2018; Published: 16 August 2018

\begin{abstract}
Phenolic compounds, while widely recognized for their biological potential, when added into food matrixes may interact with food constituents. One example of this is the interaction between phenolic compounds and proteins, that may result in the formation of complexes and alter the bioavailability of both phenolic compounds and the nutrient availability. Moreover, when adding compounds to improve the functionality of a food matrix, these interactions may compromise the perceived benefits of the additions. Nanoencapsulation has been considered one of the means to circumvent these interactions, as they may function as a physical barrier between the phenolic compounds and the matrix (preventing not only the loss of bioactivity, but eventual sensorial alterations of the foods), protect phenolic compounds through the gastrointestinal tract, and may enhance phenolic absorption through cellular endocytosis. However, despite these advantages the food industry is still limited in its nanotechnological solutions, as special care must be taken to use food-grade encapsulants which will not pose any deleterious effect towards human health. Therefore, this review aims to provide an encompassing view of the existing advantages and limitations of nanotechnology, associated with the inclusion of phenolic compounds in dairy beverages.
\end{abstract}

Keywords: phenolic compounds; nanoencapsulation; phenolic compounds-protein interaction

\section{Introduction}

Functional foods have become a staple of current dietary habits, with consumers' demands for healthier and more nutritional foods rising over the years. However, the current fast paced lifestyle, has forced the food industry to develop new technological approaches capable of fulfilling consumers' nutrition and health demands using "easy-to-eat" and "on the go" foodstuffs [1,2]. Given their portability, nutritional profile and widespread consumer acceptance, dairy beverages present themselves as an interesting base to be used to develop new functional foods. The incorporation of ingredients with potential health benefits (e.g., antioxidants), may be a possible way to improve the functional value of a product. However, the incorporation of bioactive ingredients into a food matrix poses some interesting technological challenges, an example of this is relatively straightforward: the addition of a new ingredient is likely to result in the alteration of the organoleptic characteristics of the final foodstuff. In fact polyphenols, widely reported as having interesting health promoting potential, have also been described as possessing some intrinsic color, as well as a bitter and astringent taste, that can affect the overall flavor and aspect of food products [3-5]. Nanotechnology, particularly nanoencapsulation, presents an interesting solution that may circumvent some of the sensory modifications caused by the phenolic supplementation of a given food matrix. Moreover, 
nanoencapsulation also brings other potential benefits. As phenolic compounds can interact with some food matrix components, this interaction can be attenuated through their nanoencapsulation. A well described example of this are phenolic-protein interactions that can result not only in a potential loss of functionality of both polyphenols and proteins, but also in a reduction of their bioavailability, with a subsequent reduction of the nutritional value of the foodstuff [6]. From a technological standpoint, the incorporation of phenolic compounds into foods may also present some advantages that derive from their antioxidant and antimicrobial activities (e.g., longer shelf-life and stronger resistance to contaminations), potential benefits that may also be compromised by the interaction of phenolics with food matrix components, and potentially circumvented by nanoencapsulation [7-9]. Considering the above arguments the present review aims to provide some insights into the methodologies that can be used to nanoencapsulate phenolic compounds, while contextualizing their potential application in dairy beverages.

\section{Materials and Methods}

The literature review that served as a base for the current review was compiled using Google Scholar and ScienceDirect databases, and the search was conducted using terms such as: bioactive properties of phenolic compounds, bioavailability of phenolic compounds, nanoencapsulation techniques, nanoencapsulation of phenolic compounds, phenolic-protein interaction, phenolic compounds dairy matrix, safety concerns nanoparticles, and safety concerns phenolic compounds.

\section{Results and Discussion}

\subsection{Phenolic Compounds and Health}

Diet has long been associated with positive or negative impacts upon health and wellbeing, with foodstuffs of plant origin being strongly associated with a healthier status. Most importantly, the potential benefits of their consumption have been frequently associated with the phenolic compounds present, which have long been recognized as exerting a positive influence upon human health. Polyphenols have long been studied as one of the most likely class of compounds, present in whole plant foods, which can affect physiological processes that may grant some protection against chronic diet-associated diseases. There are numerous researches which have reported the potential health benefits of these compounds, including several epidemiological studies, thus giving strength to this connection [10-15].

One of the properties most commonly associated with phenolics is antioxidant activity, as the position of the hydroxyl group bound to the aromatic ring are efficient electron donners. Moreover, phenol groups can also accept electrons resulting in the formation of relatively stable phenoxyl radicals. Consequently, this allows for the disruption of chain oxidation reactions that can be detrimental in biological systems. When in foods, they can help limit the oxidative damage of the matrix itself (allowing for longer shelf life), or after ingestion, be absorbed by the body and act as local antioxidants. For instance, anthocyanins (water soluble flavonoid pigments that are abundant in red and purple fruits) have been described as capable of protecting liver and red blood cells against in vitro and in vivo oxidative damage, and several phenolic rich extracts have been associated with the reduction of plasmatic antioxidant levels and oxidation stress markers. There are evidences that the beneficial effects attributed to dietary polyphenols depend on their biotransformation by the gut microbiota [16-23]. Phenolic compounds have also been associated to the prevention of neurodegenerative diseases (e.g., Parkinson and Alzheimer), as well as with the amelioration and/or prevention of other neurological pathologies such as memory loss, posttraumatic stress disorder (PTSD), and ischemic brain damage. Furthermore, several epidemiological studies have also linked phenolic compound's ingestion to a reduction of the risk for developing diabetes, cancer, cardiovascular, and inflammatory diseases $[15,19,24-30]$. 
It has been described that the use of phenolic compounds as ingredients can enhance the technological and nutritional properties of food, thus increasing the functionality of food products. Furthermore, non-extractable polyphenols, which are not released from the food matrix and therefore manage to reach the colon nearly intact, have been shown to exhibit health promoting properties as well, namely in relation to gastrointestinal health. The gut microbiota is responsible for converting these compounds in small size phenolics, which are better absorbed and persist in the blood for more than $48 \mathrm{~h}$, showcasing antioxidant and anti-inflammatory activity. Recent studies have shown that the intake of polyphenol extracts helps to modulate the human gut microbiota, increasing the abundance of Bifidobacteria and Lactobacilli and diminishing the presence of Clostridium histolyticum, which considering that the latter has been associated with inflammatory bowel disease, contributes to a healthier profile of the gut. Moreover, different studies have shown that phenolics can alter the Bacteroides/Firmicutes balance, with Firmicutes being more predominant in people who suffer from obesity and Bacteroides being reported as significantly contributing to the reduction of blood pressure and high-density lipoprotein cholesterol [21,31-37].

\subsection{Phenolic Compounds and Food Matrixes}

The supplementation of a foodstuff with polyphenols presents an interesting means through which functionality may be added into a food product. However, as mentioned previously, the incorporation of these compounds into complex food matrixes may result in a series of interactions with several different constituents. When considering complex protein rich matrixes like dairy products and dairy beverages, this problem gains particular relevance given the high affinity between polyphenols and proteins, resulting in interactions that may alter not only the sensory profile of the dairy products, but also the (phyto)nutrient bioavailability [38-41]. An example of these effects, results from the interaction of caseins and whey proteins with vanillin, which has been reported to result in a reduction of vanillin's flavor [41].

In general, protein-phenolic interactions are one of the best characterized interactions in literature, with both covalent and non-covalent interactions having been the subject of several revision papers [38,42-45]. Interactions between flavonoids and proteins are frequently non-specific (except when concerning enzymatic interactions) and can therefore be altered by the food matrixes composition and the presence of other, non-protein compounds. These alterations lead to conformational changes and the modification of the proteins' structure [46-48]. An example of these alterations has been reported by Aberkane, et al. [49] for complex systems such as $\beta$-lactoglobulin-gum and acacia-quercetin. These authors reported that $\beta$-lactoglobulin lost some $\beta$-sheets as the result of an increase in exposure of the protein's hydrophobic pockets. Overall, phenolic-protein interactions frequently result in the formation of complexes that result in aggregates, and eventually the precipitation of both proteins and flavonoids [48]. London forces and hydrogen bonds have also been reported to play a role in phenolic-protein interactions, in fact, Papadopoulou, et al. [50] reported that quercetin and rutin bind to bovin serum albumin more strongly than (-)-epicatechin or (+)-catechin (regardless of the hydrophilic rutinose group), as the non-polar groups of quercetin and rutin are easier to polarize than those of catechin and epicatechin. It is likely that London forces played an important role in the results reported by these authors.

Phenolics and Dairy Products

Dairy beverages have been widely described as being associated with bone health, as well as a reduction in the risk of suffering stroke, metabolic syndrome, and some cancers. Moreover, their protein-rich composition makes them an interesting, nutritious alternative to be used as a part of a healthy diet throughout the day [51]. In the past, several studies indicated that the incorporation of polyphenols into dairy matrices was not feasible given the occurrence of interactions between dairy proteins [52,53]. In vivo tests showed that the ingestion of milk fortified with epicathechin led to differences in metabolite excretion profiles; furthermore, the ingestion of blueberries in association 
with milk impairs the in vivo antioxidant properties of blueberries and reduces the absorption of caffeic and ferrulic acids [54,55]. Arts, Haenen, Wilms, Beetstra, Heijnen, Voss, and Bast [53] have shown that the antioxidant activity of several components of green and black teas, such as epigallocathein and gallic acid with $\alpha$ - and $\beta$-casein or albumin was not cumulative, but it appeared masked by an interaction and depended on the protein or flavonoid studied. Thus, the addition of milk to black tea, may result in the formation of protein-polyphenols complexes, which decrease the bioavailability of polyphenols [52,53]. Moreover, these interactions of cathechins were suggested to occur with proline rich proteins (e.g., caseins), and also with milk fat [56].

In chemical terms, plant phenolics can interact covalently or non-covalently with proteins; both ways can lead to the precipitation of proteins via either multisite interactions (several phenolics bound to one protein molecule), or multidentate interactions (one phenolic bond to several protein sites or protein molecules) [57]. Non-covalent interactions between phenolics and proteins have been suggested to be created by hydrophobic and van der Walls association, which may be subsequently stabilized by hydrogen bonding. These interactions are reversible and alter the solution properties of proteins, while covalent interactions permanently modify the structure of a protein. Furthermore, reversible associations may or may not result in protein precipitation, depending on factors such as ionic composition of solution and $\mathrm{pH}$. Protein precipitation that occurs at low ratios of protein to polyphenolic, which may be reversed as the ratio increases [40]. Moreover, from a dairy perspective, tannins, procyanidins, phenolic acids, and flavonoids have been reported as resulting in the modification of dairy globular proteins resulting in the alteration of some of their physical properties, and even their precipitation [39,58-61]. As discussed previously, protein-phenol interactions are likely to modify bioavailability of both proteins and phenols [62]. As the bioavailability and nutraceutical effects of many phenolic compounds are modified in the presence of proteins, it is of fundamental importance to understand the nature of the protein-phenolic interaction in dairy products to obtain the maximum benefit of these phenolic compounds [63].

Hence, a recent work of our research center studied the interactions of rosmarinic acid with dairy proteins $[64,65]$. Rosmarinic acid is a natural polyphenol carboxylic acid, a tannin, and an ester of caffeic acid with 3,4-dihydroxyphenyllactic acid and appears in higher amounts in families such as Boraginaceae and Lamiaceae, but in the latter, it is restricted to a subfamily, the Nepetoideae. It has been identified as one of the active components of several medicinal plants (e.g., Salvia officinalis), with several potential biological properties associated therewith, such as antioxidant, anti-mutagenic, anti-bacterial, and anti-viral capabilities. Their inclusion in any food, such as dairy matrices can contribute to an increase of the nutritional and health benefits value. Hence, the research performed, was made to study the interactions between rosmarinic acid (RA) and bovine milk whey proteins (i.e., $\alpha$-Lactoalbumin, $\beta$-Lactoglobulin and Lactoferrin) and caseins ( $\alpha$-s1-casein, $\beta$-casein and $k$-casein). Radical quenching assay (e.g., ABTS), optical density, liquid chromatography (e.g., HPLC or FPLC), dynamic light scattering and zeta-potential, Fourier transform infrared spectroscopy, and differential scanning calorimetry were used for the screening of the interactions at 0,3 , and $24 \mathrm{~h}$ of storage at $4{ }^{\circ} \mathrm{C}$. Interactions were assessed both at neutral $\mathrm{pH}$ of the complexes in water and acidic $\mathrm{pH} 3$ and 4.5. Results showed the occurrence of non-covalent interactions between RA and whey proteins and caseins, such as hydrophobic, hydrogen bonding, and dipole-dipole type. Radical quenching activity of RA decreased in the presence of milk proteins, yet at the initial time especially in the case of $\alpha$-Lactoalbumin, $\alpha$-s1-casein and $\beta$-casein, meaning that amount of free polyphenol diminished. Complex dimension was different depending on $\mathrm{pH}$, and on primary and secondary structure of proteins. Interactions showed to be favored at the lowest $\mathrm{pH}$, and reversible in all the cases; nonetheless, complexes RA-proteins were more stable than proteins alone. 


\subsection{Nanoencapsulation}

While several reasons can be found to justify the importance of encapsulating polyphenolic compounds, they can be split into two major groups, one that is due to technological aspects of their incorporation into a matrix and another that is linked to their biological properties.

As discussed previously, the inclusion of polyphenols into a matrix may pose some difficulties, not only because of their interactions with the food matrix, but also because the incorporation itself may not be a straight forward process or lead to organoleptic changes. An example of this is the difficulty in incorporating compounds with a relatively low water solubility, like essential oils or resveratrol; a limitation that proved to be effectively overcome through their incorporation into cyclodextrin based nanoparticles [66-69]. From an organoleptic standpoint, the encapsulation of polyphenols may contribute to improve the characteristics of the product (for essential oils the nanoencapsulation process results in a reduction of their volatility which will prolong their aromatic properties), but may also mask any negative impact the compounds themselves may have (e.g., hide the astringency of the compounds) $[66,70,71]$.

On a different perspective, the eventual biological potential of polyphenolic compounds is intrinsically linked with their bioavailability. This means that it is dependent on their stability both in the food products and through the gastrointestinal tract, as well as their absorption through the gut epithelium [72]. Nanoparticles have been known to aid in all these aspects. They act as barriers protecting the encapsulated polyphenols from the environment of the different digestive compartments and may enhance absorption by endocytosis or through specific targeting [73-77]. Resveratrol, for example, is a polyphenolic compound that has a reduced bioavailability, not only due to its sensitivity to the digestive process, but also because of its low cellular absorption. Moreover, to benefit from resveratrol's potential benefits, an average person must absorb around $50 \mathrm{mg}$, so the final plasmatic concentration is ca. $10 \mathrm{mg}$ per liter of blood [78-80]. Considering this, several authors have reported that the nanoencapsulation of resveratrol is an important factor to not only to improve cell uptake, but also because it facilitates its absorption and protects it from degradation during its passage through the gastrointestinal tract [67,80-84].

\subsubsection{Nanoencapsulation Techniques}

Several of the physicochemical properties of a nanoparticle (such as size, surface area, shape, solubility, polydispersity, or encapsulation efficiency), will vary with the encapsulation technique employed to produce them. A top-down approach, e.g., emulsification (with or without solvent evaporation) or drying, implies the use of precise tools to control the size reduction and shape of the nanomaterial, or a bottom-up approach where some self-assembly/organization of the particles occurs, e.g., supercritical fluid technique, nanoprecipitation, inclusion complexation, and coacervation. All of these techniques have been reported as being capable of encapsulating phenolic compounds [85-92].

Emulsion is a technique used to encapsulate both lipophilic (oil in water emulsion) and the more common hydrophilic (water in oil emulsion) polyphenols, which results in a colloidal mixture of nanoparticles (i.e., nanoemulsion) that is relatively stable; and has a low viscosity and appears transparent to the naked eye. The nanoemulsions are typically produced by mixing two immiscible liquids, which are then dispersed to yield nanoparticles populations with relatively low size distributions [93-95]. Kunieda et al. [96] reported that a methodology that supplies the energy in the shortest time and most constant manner, yields the smallest nanoparticles and smaller size intervals, though the dispersion itself may be carried out using an array of different means, like microfluidisation (high pressure; up to 20,000 psi) or ultrasonication [95,97]. A variation of this technique pairs it with solvent evaporation (emulsification-solvent evaporation). This implies the emulsification of a polymer (e.g., ethyl cellulose or polylactic acid) into the aqueous phase, followed by induction of the polymer's precipitation through the evaporation of its solvent. The size of the resulting particles can be adjusted through the control of the stir rate, temperature, type/amount of dispersing agents, and the 
overall viscosity of the phases with Zambaux et al. [98] reporting that, to attain small particles sizes, ultrasonication or high stirring velocities may be required $[95,98,99]$.

Supercritical fluids, liquids or gases at the vapor-liquid critical point, exhibit properties that are intermediate between liquids and gases (e.g., low viscosity, low density, or high solvating power), which in turn, can be used to nanoencapsulate compounds using an array of different techniques $[78,100]$. Supercritical antisolvent precipitation is one of the most commonly employed methods. It is based on the dissolution of a liquid solution (containing the polyphenolic) in a supercritical fluid (miscible with the liquid solution, but unable to dissolve the polyphenolic), which results in the expansion of the liquid phase and the precipitation of nanoparticles [101,102].

The nanoprecipitation method, also known as solvent displacement, is based on the interfacial deposition of a polymer as a result of the displacement of a semi-polar solvent, miscible in water, from a lipophilic solution to a hydrophilic one [103]. This method allows for the relatively fast production of nanoparticles, with a size ranging from 50 to $300 \mathrm{~nm}$, while requiring a small amount of raw materials and energy [104-107]. However, the traditional approach is not very effective on water soluble compounds like polyphenols [108]. To circumvent this limitation, a two-step nanoprecipitation method has been developed, where the first step implies the precipitation of the active ingredient by the solvent, which generates nanoparticles that are then dissolved by another solvent, and a second nanoprecipitation is promoted to encapsulate the active ingredient [104,109].

Another possibility is the encapsulation of a polyphenol through the establishment of an interaction (hydrogen bonding, van der Walls, or hydrophobic interactions) with a substrate. The most commonly used substrate are cyclodextrins, as their cylinder-shaped structure, hydrophobic interior, and hydrophilic exterior make them particularly interesting to encapsulate less polar polyphenols (like essential oils, quercetin, or resveratrol), while increasing their water solubility with smaller more hydrophobic polyphenols having a higher affinity for the cyclodextrins [66-69].

Most of the above-mentioned techniques result in liquid suspensions of nanoparticles which poses some stability limitations, like leakage of the encapsulated ingredients or the aggregation of the nanoparticles. Limitations that may be circumvented if the particles are in a solid state/phase [110]. Freeze and spray drying are two techniques commonly used to attain dry, more stable nanoparticles. However, the conditions in which the drying occurs are relevant not only for the stabilization of the nanoparticles, but also to minimize the stress induced by the drying process to the nanoparticles [110].

\subsubsection{Common Types of Nanoparticles}

In many of the in vitro studies, the amounts of bioactive compounds that exert some potential against some disease, are used in amounts significantly higher than those to which humans are exposed to through the diet or that could be found in the blood. Their content after absorption, as well as their metabolites, determines their bioactivity and potential impact on health. Major barriers for some compounds are their poor water solubility and susceptibility to alkaline conditions, light, oxygen exposure, and heat which also limit their clinical efficacy. Encapsulation has been used to overcome most of the drawbacks and is defined as a process in which tiny particles or droplets of a micro-component are surrounded by another material called wall material/coating/carrier, or are embedded in a homogeneous or heterogeneous matrix resulting in the formation of small capsules [111].

Nanoparticles with entrapped nutraceuticals are generated by adding a water-miscible solvent solution of the nutraceutical, and a water-insoluble polymer to water (with or without a surfactant). In this process, the polymer condenses and aggregates, and some of the nutraceutical is trapped inside the polymer. One commonly used polymer is poly(lactic-co-glycolic acid), or PLGA, which is biodegradable and biocompatible and is approved by the US FDA for therapeutic usage [112].

Polysaccharides, due to their abundance and wide availability, are frequently used as encapsulation material. Characterized accordingly to their biological origin (plant-starch, cellulose, pectin, and guar gum; animal-chitosan; algal-alginate and carrageenan; microbial-xanthan, dextran 
and cyclodextrins), they are stable, non-toxic molecules that can be easily modified [113]. Additionally, they possess technologically relevant properties, such as biodegradability, hydrophilicity, and gel formation capacity, which makes them interesting as materials to be used in targeted drug delivery systems [114]. Acetylated starch has been used to encapsulate food and flavor ingredients [115], with the acetylation process enhancing hydrophobicity, resistance to enzymatic hydrolysis and reducing swelling of the fibers, all attributes which are deemed useful in food delivery systems [116]. Similarly, native guar gums have been depolymerized using partial hydrolysis (with acids, enzymes, heat induced acid hydrolysis, and other methods) to overcome their natural high viscosity. They can then be included in food delivery systems, such as an alginate matrix, along with a cross linking agent (glutaraldehyde) to overcome their rapid dissolution for targeted nutrients delivery [117]. Another example is chitosan, a polysaccharide obtained from the deacetylation of chitin, which can be used to produce chitosan-tripolyphosphate (TPP) through an ionic-gelation procedure. These chitosan nanoparticles can be used to control the release profile of bioactives in the intestine, and have been applied in encapsulation of catechins [118] and rutin [119]. However, there are still some drawbacks regarding the usage of carbohydrate-based delivery systems, as a fundamental lack of understanding of the major factors governing the rational design of these systems for particular applications exists. Despite its great potential for future works, knowledge regarding their toxicity, residual solvent analysis, and evaluation of their biological fate during digestion, absorption, and excretion should be pursued [113].

Another example of a commonly used nanoparticle system, are Solid lipid nanoparticles (SLNs). These nanoparticles were first introduced in the early 1990s, and can be characterized by their small particle size $(50-100 \mathrm{~nm})[77,120]$ and lack of toxicity, which makes them important colloidal carriers because they combine advantages, such as physical stability, controlled release, and excellent tolerability, being one of the most currently used systems [121,122]. The reduction of particle size and the use of non-toxic materials, make these particles important colloidal carriers because they combine advantages such as physical stability, controlled release and excellent tolerability, characteristics that make them one of the most currently used systems [121,122]. They are obtained through nanoemulsification of lipid matrixes, which contain melting points above room and body temperature [such as triglycerides, mono, di and triglycerides mixtures (witepsol bases), waxes (beewax, cetyl palmitate), hard fats (stearic acid and palmitic acid), or other types of lipids such as paraffin], with common emulsifiers such as poloxamer and 302 polysorbate 20,60 and 80, lecithin, tyloxapol, sodium cholate, and sodium glycocholate, among others [118]. Their fabrication can be obtained through different technologies [high shear homogenization, ultrasound, high pressure homogenization (cold homogenization and hot homogenization), solvent emulsification/evaporation, and microemulsion method] [123]. Some of their main advantages are the possibility of improving the stability of the incorporated compounds; thermal stability; increased oral bioavailability of compounds (particularly lipophilic molecules), e.g., labile drug molecules can be protected from the external environment (during storage); protection from the digestive process (following oral administration); and the scaling up of the formulation technique to industrial production level is feasible at low cost and in a relatively simple way [124]. On the contrary, several disadvantages are also associated with SLNs dispersions namely, they may contain a high amount of water, drug-loading capacity of SLNs are limited due to the crystalline structure of solid lipid, expulsion of encapsulated drug may take place during storage, drug release profile may change with storage time, polymorphic transitions are possible, and growth is possible during storage $[125,126]$. Several drugs (hydrophobic and hydrophilic) have been incorporated in the SLN formulations and in most cases the aim was to improve oral bioavailability, either by increasing gastrointestinal absorption or by bypassing the first-pass metabolism. Hydrophilic drugs can also be incorporated in SLNs, but such procedure is considered to be challenging because of the affinity between the drug and the lipid, and the tendency of partitioning the encapsulated molecules in the water during the production process of nanoparticles $[123,124,127]$. 


\subsubsection{Nanoencapsulation of Phenolic Compounds}

The application of nanotechnology to the food sector could generate innovation in the macroscale characteristics of food, such as texture, taste, and other sensory attributes like coloring, strength, processability, and stability during shelf-life leading to a great number of new products. Moreover, nanotechnology can also improve the water solubility, thermal stability, and oral bioavailability of bioactive compounds $[8,9,128,129]$. The food industry is limited to the use of food-grade ingredients for encapsulation (e.g., proteins, carbohydrates, fats, and food-grade emulsifiers), and there is still a large need in target release of bioactives in the body via encapsulation technologies which use food-grade encapsulants. This will require control over permeability, rupture stress properties, and enzyme-degradation kinetics of encapsulant materials in response to a variety of trigger mechanisms for the release of encapsulated nutrients or bioactives [93]. At present, applications of nanotechnology in food industries include nanocomposites (hybrid nanostructured materials) in food packaging material for controlling diffusion and microbial protection, nanobiosensors for detection of contamination and quality deterioration, and nanoencapsulation or nanocarrier for controlled delivery of nutraceuticals [72,74,130,131].

Foods fortified with encapsulated fish oils have been reported in recent years, and they include beverages, dressings (salad dressings, mayonnaise, margarines), dairy products (ice cream, cheese, flavored milk), and powdered products (infant formula, dairy products) [9]. Encapsulating natural antioxidants, such as vitamin E, C and flavonoids (quercetin, catechin) is a promising way of protecting and incorporating the bioavailability of these components [132].

To improve stability of blackcurrant anthocyanin, the pomace was mixed with maltodextrin and inulin, representing a good additive for incorporation into functional foods [133]. (+)-Catechin or green tea extract were encapsulated in soy lecithin nanoliposomes and incorporated into a full-fat cheese, then ripened at $8{ }^{\circ} \mathrm{C}$ for 90 days demonstrating the potential for using cheese as a delivery vehicle for green tea antioxidants [134]. Zein, a biocompatible, biodegradable macromolecule was employed for nanoencapsulation of green tea catechins by electrospraying technique, and the catechins had significantly improved in vitro gastrointestinal stability and Caco-2 cell monolayer permeability compared to unencapsulated catechins [135]. Compounds with low hydrophilicity, like quercetin, were incorporated into solid lipid nanoparticles using an emulsification at low-temperature solidification method. As quercetin's in vivo effects are dependent on its absorption and bioavailability, the use of these types of nanoparticles to fortify dairy beverages may not only result in the protection of the compound's bioactivity, but actually contribute to its improvement [76]. Resveratrol is a natural polyphenolic phytoalexin, found in various common foods, that has been described as having potentially significant beneficial effects on health. However, like with quercetin, resveratrol suffers from a low and variable oral bioavailability, a limitation that can be overcome through the use of SLNs [136]. Moreover, the use of SLNs loaded with polyphenols in dairy matrices has already been successfully reported, hinting that their use in the development of fortified dairy beverages may be an interesting alternative to exploit, particularly when considering compounds with a low bioavailability. In particular, this process has been associated not only with a lack of non-specific interactions with the matrix, but also with granting some protection to the bioactive molecules throughout the digestive process [137]. This last process has been described in a work that focused on the protection granted by SLNs to rosmarinic acid and a herbal extract, against digestion mediated degradation $[124,138]$.

To the best of our knowledge, relatively few authors focus on the organoleptic impact of using dairy beverages fortified with nanoencapsulated phenolic compounds. Fathi, et al. [139] studied the potential use of SLNs as a means to incorporate hesperetin (a low solubility flavonoid) into a milk sample, with the sensory analysis reporting that the nanoencapsulation was successful in masking the bitter taste and aftertaste of hesperetin, whilst masking the alterations in homogeneity and color that resulted from the straightforward addition of this flavonoid $[139,140]$. This example represents a clear illustration of the potential for using nanoencapsulated ingredients, particularly polyphenolics, towards the development of improved foodstuffs, without the loss of sensory quality. Overall, for an 
encapsulated ingredient to be successful in the market place, it must be tested in the final food product, taking into account the storage stability of the encapsulated ingredient, its compatibility with the food matrix, the processing stresses it has to withstand during food manufacture when it is in intimate contact with other ingredients, and how it breaks down when consumed. With respect to the storage stability of the encapsulated ingredients, powdered formats in the glassy state have the advantages of convenience, ease of transport, and improved storage stability over equivalent liquid formulations. Microencapsulated powders can be used for blending with other dry ingredients, or incorporated as powders into some food products at various stages during the manufacturing process, or reconstituted prior to incorporation into liquid products [141].

\subsection{Safety Concerns}

Nanotechnology has been revolutionizing the entire food system from production to processing, storage, and development of innovative materials, products, and applications. Nanoparticles, to be used in the food industry must be prepared using materials and technologies that are food grade. However, the assumption of safety when dealing with nanomaterials is not as straight forward. When manipulated at a nanoscale level, materials exhibit properties that are not found at the macro-scale level, which means that products that are recognized as safe may present an unforeseen risk. As nanoparticles may allow for larger concentrations of compounds to reach the tissues, they could also cause harmful imbalances to the homeostasis. Moreover, the same concern can be considered when contemplating the nanoparticles themselves, regardless of their content. Therefore, it is important to perform a toxicity/safety assessment whenever their inclusion into food products is considered. The understanding of the bio-kinetic profile of nanoparticles for the different organs may allow for the identification of the areas with a larger risk of adverse reactions [142,143]. The gastrointestinal uptake of nanoparticles, depends on their capacity to migrate through the mucous, contact with the gut epithelium, and consequent translocation process (direct passage through the tight junctions or through the transcellular route) [77,144-147]. Typically, smaller nanoparticles migrate faster than the larger ones; cationic particles have been described to remain in the mucus barrier, while negatively charged particles reach the endothelium, and should they be effectively protected from local degradation/metabolization, they can then reach the circulatory system, spread throughout the body, and either accumulate or be excreted [148-150]. The nanoparticles interaction with blood components and their intrinsic properties will be a determinant factor in their fate. Hydrophobic nanoparticles can be sequestered within the liver or spleen, and smaller particles are more widespread than their larger counterparts [146,150-153]. This means that, while the literature that contemplates the toxicity of nanoparticles has been expanding, it should be taken into account that the results that are obtained for one size and charge may not be the same as those observed for a different nanoparticle, and perhaps the tissues to be considered must also be different [144].

From a regulatory standpoint, most food safety agencies have yet to propose specific regulations for "nanoproducts", leaving a regulatory vacuum behind. The European Union and associated regulatory councils, have stated that there must be an adjustment of the legislation, guidelines, and guidance documents when including nanoparticles, but the overall lack of knowledge has this process in a relative standstill. A similar lack of legislation can be found in other regions worldwide. In the United States of America, the Food and Drug Administration has no regulations that contemplate nanotechnologies as they regulate "products, not technologies", meaning that the actual regulatory framework for a given product can only be established well after the product is developed [144,154]. Despite this, some existing American laws (e.g., Toxic Substances Control Act or the Food, Drug and Cosmetic Act) provide some legal framework. The United Kingdom's government commissioned a study, carried out by the Royal Society and the Royal Academy of Engineering, contemplating the pros and cons of nanotechnology. From this study emerged a recommendation to treat nanoparticles as a new substance, and therefore follow the same regulatory procedures already established by the European Union [154]. Regardless, some authors have already reported on the safety profile 
of Witepsol or carnauba's SLN loaded with rosmarinic acid, with the reported data demonstrating that neither type of nanoparticle exhibited no in vitro genotoxicity or cytotoxicity, and had a in vivo safety profile in rats (orally treated) [155]. These results, seem to indicate that at least where SLNs are concerned, they present an interesting alternative to be exploited when considering the design of new, sensory appealing dairy beverages, with improved functional profiles, and without the loss of any nutritional value.

\section{Conclusions}

Overall this review shows that nanoencapsulation based approaches possess great potential as tools for the development of functional beverages, which may combine the benefits of dairy products with the known biological properties of phenolic compounds, without resulting in a loss of sensory or nutritional quality. However, despite the potentials associated with this technology, it is still not market ready, as the lack of specific legislation, regulatory procedures, and compounds validation limits its development and implementation.

Author Contributions: S.S. described the nanoencapsulation process and its potential, M.V. and E.C. described the biological potential of phenolic compounds and the concerns associated with the use of nanoencapsulated phenolic compounds. A.R.M. and A.L.S.O. worked on the description of the interactions between phenolic compounds and proteins while M.P. supervised all the work and was responsible for its correction.

Funding: This work was supported by Fundação para a Ciência e Tecnologia [projects UID/Multi/50016/2013 and Multibiorefinery (POCI-01-0145-FEDER-01640)] and through QREN-ANI [project Ecotex (17819)]. Author E.M. Costa was funded by Fundação para a Ciência e Tecnologia and Aquitex S.A. [grant SFRH/BDE/103957/2014]. No funds were received for covering the costs to publish in open access.

Conflicts of Interest: The authors declare no conflict of interest.

\section{References}

1. Oliveira, A.; Amaro, A.L.; Pintado, M. Impact of food matrix components on nutritional and functional properties of fruit-based products. Curr. Opin. Food Sci. 2018, 22, 153-159. [CrossRef]

2. Tiwari, U. Chapter 14-production of fruit-based smoothies fruit juices. In Fruit Juices—Extraction Composition and Analysis; Rajauria, G., Tiwari, B.K., Eds.; Academic Press: London, UK, 2018; pp. 261-278.

3. Lesschaeve, I.; Noble, A.C. Polyphenols: Factors influencing their sensory properties and their effects on food and beverage preferences. Am. J. Clin. Nutr. 2005, 81, 330S-335S. [CrossRef] [PubMed]

4. Gutiérrez-Rosales, F.; Rios, J.; Gomez-Rey, M.L. Main polyphenols in the bitter taste of virgin olive oil. Structural confirmation by on-line high-performance liquid chromatography electrospray ionization mass spectrometry. J. Agric. Food Chem. 2003, 51, 6021-6025. [CrossRef] [PubMed]

5. Bedini, A.; Zanolli, V.; Zanardi, S.; Bersellini, U.; Dalcanale, E.; Suman, M. Rapid and simultaneous analysis of xanthines and polyphenols as bitter taste markers in bakery products by FT-NIR spectroscopy. Food Anal. Methods 2013, 6, 17-27. [CrossRef]

6. Budryn, G.; Zaczyńska, D.; Oracz, J. Effect of addition of green coffee extract and nanoencapsulated chlorogenic acids on aroma of different food products. LWT 2016, 73, 197-204. [CrossRef]

7. Barras, A.; Mezzetti, A.; Richard, A.; Lazzaroni, S.; Roux, S.; Melnyk, P.; Betbeder, D.; Monfilliette-Dupont, N. Formulation and characterization of polyphenol-loaded lipid nanocapsules. Int. J. Pharm. 2009, 379, $270-277$. [CrossRef] [PubMed]

8. Silva, H.D.; Cerqueira, M.A.; Vicente, A.A. Nanoemulsions for food applications: Development and characterization. Food Bioprocess Technol. 2012, 5, 854-867. [CrossRef]

9. Huang, Q.; Yu, H.; Ru, Q. Bioavailability and delivery of nutraceuticals using nanotechnology. J. Food Sci. 2010, 75, R50-R57. [CrossRef] [PubMed]

10. Du, H.; Li, L.; Bennett, D.; Guo, Y.; Key, T.J.; Bian, Z.; Sherliker, P.; Gao, H.; Chen, Y.; Yang, L. Fresh fruit consumption and major cardiovascular disease in china. N. Engl. J. Med. 2016, 374, 1332-1343. [CrossRef] [PubMed] 
11. McCullough, M.L.; Peterson, J.J.; Patel, R.; Jacques, P.F.; Shah, R.; Dwyer, J.T. Flavonoid intake and cardiovascular disease mortality in a prospective cohort of us adults. Am. J. Clin. Nutr. 2012, 95, 454-464. [CrossRef] [PubMed]

12. Mink, P.J.; Scrafford, C.G.; Barraj, L.M.; Harnack, L.; Hong, C.-P.; Nettleton, J.A.; Jacobs, D.R., Jr. Flavonoid intake and cardiovascular disease mortality: A prospective study in postmenopausal women. Am. J. Clin. Nutr. 2007, 85, 895-909. [CrossRef] [PubMed]

13. Terauchi, M.; Horiguchi, N.; Kajiyama, A.; Akiyoshi, M.; Owa, Y.; Kato, K.; Kubota, T. Effects of grape seed proanthocyanidin extract on menopausal symptoms, body composition, and cardiovascular parameters in middle-aged women: A randomized, double-blind, placebo-controlled pilot study. Menopause 2014, 21, 990-996. [CrossRef] [PubMed]

14. Mursu, J.; Voutilainen, S.; Nurmi, T.; Tuomainen, T.-P.; Kurl, S.; Salonen, J.T. Flavonoid intake and the risk of ischaemic stroke and cvd mortality in middle-aged finnish men: The kuopio ischaemic heart disease risk factor study. Br. J. Nutr. 2008, 100, 890-895. [CrossRef] [PubMed]

15. Selma, M.V.; Espín, J.C.; Tomás-Barberán, F.A. Interaction between phenolics and gut microbiota: Role in human health. J. Agric. Food Chem. 2009, 57, 6485-6501. [CrossRef] [PubMed]

16. Duda-Chodak, A.; Tarko, T.; Satora, P.; Sroka, P. Interaction of dietary compounds, especially polyphenols, with the intestinal microbiota: A review. Eur. J. Nutr. 2015, 54, 325-341. [CrossRef] [PubMed]

17. Youdim, K.A.; Martin, A.; Joseph, J.A. Incorporation of the elderberry anthocyanins by endothelial cells increases protection against oxidative stress. Free Radic. Biol. Med. 2000, 29, 51-60. [CrossRef]

18. Liu, W.; Lu, X.; He, G.; Gao, X.; Li, M.; Wu, J.; Li, Z.; Wu, J.; Wang, J.; Luo, C. Cytosolic protection against ultraviolet induced DNA damage by blueberry anthocyanins and anthocyanidins in hepatocarcinoma hepg2 cells. Biotechnol. Lett. 2013, 35, 491-498. [CrossRef] [PubMed]

19. Sevgi, K.; Tepe, B.; Sarikurkcu, C. Antioxidant and DNA damage protection potentials of selected phenolic acids. Food Chem. Toxicol. 2015, 77, 12-21. [CrossRef] [PubMed]

20. Wang, Y.-P.; Cheng, M.-L.; Zhang, B.-F.; Mu, M.; Zhou, M.-Y.; Wu, J.; Li, C.-X. Effect of blueberry on hepatic and immunological functions in mice. Hepatobiliary Pancreat. Dis. Int. 2010, 9, 164-168. [PubMed]

21. Yan, S.; Shao, H.; Zhou, Z.; Wang, Q.; Zhao, L.; Yang, X. Non-extractable polyphenols of green tea and their antioxidant, anti- $\alpha$-glucosidase capacity, and release during in vitro digestion. J. Funct. Foods 2018, 42, 129-136. [CrossRef]

22. Silva, S.; Costa, E.M.; Vicente, S.; Veiga, M.; Calhau, C.; Morais, R.M.; Pintado, M.E. DNA agarose gel electrophoresis for antioxidant analysis: Development of a quantitative approach for phenolic extracts. Food Chem. 2017, 233, 45-51. [CrossRef] [PubMed]

23. Olas, B. The multifunctionality of berries toward blood platelets and the role of berry phenolics in cardiovascular disorders. Platelets 2017, 28, 540-549. [CrossRef] [PubMed]

24. Albishi, T.; John, J.A.; Al-Khalifa, A.S.; Shahidi, F. Antioxidant, anti-inflammatory and DNA scission inhibitory activities of phenolic compounds in selected onion and potato varieties. J. Funct. Foods 2013, 5, 930-939. [CrossRef]

25. Bulotta, S.; Celano, M.; Lepore, S.M.; Montalcini, T.; Pujia, A.; Russo, D. Beneficial effects of the olive oil phenolic components oleuropein and hydroxytyrosol: Focus on protection against cardiovascular and metabolic diseases. J. Transl. Med. 2014, 12, 219. [CrossRef] [PubMed]

26. Nohynek, L.J.; Alakomi, H.-L.; Kähkönen, M.P.; Heinonen, M.; Helander, I.M.; Oksman-Caldentey, K.-M.; Puupponen-Pimiä, R.H. Berry phenolics: Antimicrobial properties and mechanisms of action against severe human pathogens. Nutr. Cancer 2006, 54, 18-32. [CrossRef] [PubMed]

27. Ranilla, L.G.; Kwon, Y.-I.; Apostolidis, E.; Shetty, K. Phenolic compounds, antioxidant activity and in vitro inhibitory potential against key enzymes relevant for hyperglycemia and hypertension of commonly used medicinal plants, herbs and spices in latin america. Bioresour. Technol. 2010, 101, 4676-4689. [CrossRef] [PubMed]

28. Rodríguez-Roque, M.J.; Rojas-Graü, M.A.; Elez-Martínez, P.; Martín-Belloso, O. Soymilk phenolic compounds, isoflavones and antioxidant activity as affected by in vitro gastrointestinal digestion. Food Chem. 2013, 136, 206-212. [CrossRef] [PubMed]

29. Valdés, L.; Cuervo, A.; Salazar, N.; Ruas-Madiedo, P.; Gueimonde, M.; González, S. The relationship between phenolic compounds from diet and microbiota: Impact on human health. Food Funct. 2015, 6, 2424-2439. [CrossRef] [PubMed] 
30. Wallace, T.C. Anthocyanins in cardiovascular disease. Adv. Nutr. Int. Rev. J. 2011, 2, 1-7. [CrossRef] [PubMed]

31. Landete, J. Updated knowledge about polyphenols: Functions, bioavailability, metabolism, and health. Crit. Rev. Food Sci. Nutr. 2012, 52, 936-948. [CrossRef] [PubMed]

32. González-Sarrías, A.; Espín, J.C.; Tomás-Barberán, F.A. Non-extractable polyphenols produce gut microbiota metabolites that persist in circulation and show anti-inflammatory and free radical-scavenging effects. Trends Food Sci. Technol. 2017, 69, 281-288. [CrossRef]

33. Pérez-Jiménez, J.; Díaz-Rubio, M.E.; Saura-Calixto, F. Non-extractable polyphenols, a major dietary antioxidant: Occurrence, metabolic fate and health effects. Nutr. Res. Rev. 2013, 26, 118-129. [CrossRef] [PubMed]

34. Boto-Ordóñez, M.; Urpi-Sarda, M.; Queipo-Ortuño, M.I.; Tulipani, S.; Tinahones, F.J.; Andres-Lacueva, C. High levels of bifidobacteria are associated with increased levels of anthocyanin microbial metabolites: A randomized clinical trial. Food Funct. 2014, 5, 1932-1938. [CrossRef] [PubMed]

35. Boulangé, C.L.; Neves, A.L.; Chilloux, J.; Nicholson, J.K.; Dumas, M.-E. Impact of the gut microbiota on inflammation, obesity, and metabolic disease. Genome Med. 2016, 8, 42. [CrossRef] [PubMed]

36. Vendrame, S.; Daugherty, A.; Kristo, A.S.; Riso, P.; Klimis-Zacas, D. Wild blueberry (vaccinium angustifolium) consumption improves inflammatory status in the obese zucker rat model of the metabolic syndrome. J. Nutr. Biochem. 2013, 24, 1508-1512. [CrossRef] [PubMed]

37. Hidalgo, M.; Oruna-Concha, M.J.; Kolida, S.; Walton, G.E.; Kallithraka, S.; Spencer, J.P.; de Pascual-Teresa, S. Metabolism of anthocyanins by human gut microflora and their influence on gut bacterial growth. J. Agric. Food Chem. 2012, 60, 3882-3890. [CrossRef] [PubMed]

38. Bennick, A. Interaction of plant polyphenols with salivary proteins. Crit. Rev. Oral Biol. Med. 2002, 13, 184-196. [CrossRef] [PubMed]

39. Jöbstl, E.; O'Connell, J.; Fairclough, J.P.A.; Williamson, M.P. Molecular model for astringency produced by polyphenol/protein interactions. Biomacromolecules 2004, 5, 942-949. [CrossRef] [PubMed]

40. Luck, G.; Liao, H.; Murray, N.J.; Grimmer, H.R.; Warminski, E.E.; Williamson, M.P.; Lilley, T.H.; Haslam, E. Polyphenols, astringency and proline-rich proteins. Phytochemistry 1994, 37, 357-371. [CrossRef]

41. Hansen, A.P.; Heinis, J.J. Decrease of vanillin flavor perception in the presence of casein and whey proteins1. J. Dairy Sci. 1991, 74, 2936-2940. [CrossRef]

42. De Freitas, V.; Mateus, N. Protein/polyphenol interactions: Past and present contributions. Mechanisms of astringency perception. Curr. Org. Chem. 2012, 16, 724-746. [CrossRef]

43. Papadopoulou, A.; Frazier, R.A. Characterization of protein-polyphenol interactions. Trends Food Sci. Technol. 2004, 15, 186-190. [CrossRef]

44. Siebert, K.J. Effects of protein-polyphenol interactions on beverage haze, stabilization, and analysis. J. Agric. Food Chem. 1999, 47, 353-362. [CrossRef] [PubMed]

45. Xiao, J.; Kai, G. A review of dietary polyphenol-plasma protein interactions: Characterization, influence on the bioactivity, and structure-affinity relationship. Crit. Rev. Food Sci. Nutr. 2012, 52, 85-101. [CrossRef] [PubMed]

46. Xi, J.; Guo, R. Interactions between flavonoids and hemoglobin in lecithin liposomes. Int. J. Biol. Macromol. 2007, 40, 305-311. [CrossRef] [PubMed]

47. Bourassa, P.; Kanakis, C.; Tarantilis, P.; Pollissiou, M.; Tajmir-Riahi, H. Resveratrol, genistein, and curcumin bind bovine serum albumin. J. Phys. Chem. B 2010, 114, 3348-3354. [CrossRef] [PubMed]

48. Liang, L.; Tajmir-Riahi, H.; Subirade, M. Interaction of $\beta$-lactoglobulin with resveratrol and its biological implications. Biomacromolecules 2007, 9, 50-56. [CrossRef] [PubMed]

49. Aberkane, L.; Jasniewski, J.; Gaiani, C.; Hussain, R.; Scher, J.; Sanchez, C. Structuration mechanism of $\beta$-lactoglobulin-acacia gum assemblies in presence of quercetin. Food Hydrocoll. 2012, 29, 9-20. [CrossRef]

50. Papadopoulou, A.; Green, R.J.; Frazier, R.A. Interaction of flavonoids with bovine serum albumin: A fluorescence quenching study. J. Agric. Food Chem. 2005, 53, 158-163. [CrossRef] [PubMed]

51. Weaver, C.M. Role of dairy beverages in the diet. Physiol. Behav. 2010, 100, 63-66. [CrossRef] [PubMed]

52. Kyle, J.A.; Morrice, P.C.; McNeill, G.; Duthie, G.G. Effects of infusion time and addition of milk on content and absorption of polyphenols from black tea. J. Agric. Food Chem. 2007, 55, 4889-4894. [CrossRef] [PubMed] 
53. Arts, M.J.; Haenen, G.R.; Wilms, L.C.; Beetstra, S.A.; Heijnen, C.G.; Voss, H.-P.; Bast, A. Interactions between flavonoids and proteins: Effect on the total antioxidant capacity. J. Agric. Food Chem. 2002, 50, 1184-1187. [CrossRef] [PubMed]

54. Serafini, M.; Ghiselli, A.; Ferro-Luzzi, A. In vivo antioxidant effect of green and black tea in man. Eur. J. Clin. Nutr. 1996, 50, 28-32. [PubMed]

55. Roura, E.; Andrés-Lacueva, C.; Estruch, R.; Bilbao, M.L.M.; Izquierdo-Pulido, M.; Lamuela-Raventós, R.M. The effects of milk as a food matrix for polyphenols on the excretion profile of cocoa (-)-epicatechin metabolites in healthy human subjects. Br. J. Nutr. 2008, 100, 846-851. [CrossRef] [PubMed]

56. Ryan, L.; Petit, S. Addition of whole, semiskimmed, and skimmed bovine milk reduces the total antioxidant capacity of black tea. Nutr. Res. 2010, 30, 14-20. [CrossRef] [PubMed]

57. Rawel, H.M.; Meidtner, K.; Kroll, J. Binding of selected phenolic compounds to proteins. J. Agric. Food Chem. 2005, 53, 4228-4235. [CrossRef] [PubMed]

58. Prigent, S.V.; Gruppen, H.; Visser, A.J.; Van Koningsveld, G.A.; De Jong, G.A.; Voragen, A.G. Effects of non-covalent interactions with 5-O-caffeoylquinic acid (chlorogenic acid) on the heat denaturation and solubility of globular proteins. J. Agric. Food Chem. 2003, 51, 5088-5095. [CrossRef] [PubMed]

59. Prigent, S.V.E.; Voragen, A.G.J.; van Koningsveld, G.A.; Baron, A.; Renard, C.M.G.C.; Gruppen, H. Interactions between globular proteins and procyanidins of different degrees of polymerization. J. Dairy Sci. 2009, 92, 5843-5853. [CrossRef] [PubMed]

60. Yuksel, Z.; Avci, E.; Erdem, Y.K. Characterization of binding interactions between green tea flavanoids and milk proteins. Food Chem. 2010, 121, 450-456. [CrossRef]

61. Arroyo-Maya, I.J.; Campos-Terán, J.; Hernández-Arana, A.; McClements, D.J. Characterization of flavonoid-protein interactions using fluorescence spectroscopy: Binding of pelargonidin to dairy proteins. Food Chem. 2016, 213, 431-439. [CrossRef] [PubMed]

62. Le Bourvellec, C.; Renard, C. Interactions between polyphenols and macromolecules: Quantification methods and mechanisms. Crit. Rev. Food Sci. Nutr. 2012, 52, 213-248. [CrossRef] [PubMed]

63. Hassan, Z.; El Din, H.M.F.; Ali, A.; Mehanna, N.S.; El-Messery, T. Interaction of some low molecular weight phenolics with milk proteins. World Appl. Sci. J. 2013, 23, 182-187.

64. Ferraro, V.; Madureira, A.R.; Fonte, P.; Sarmento, B.; Gomes, A.M.; Pintado, M.E. Evaluation of the interactions between rosmarinic acid and bovine milk casein. RSC Adv. 2015, 5, 88529-88538. [CrossRef]

65. Ferraro, V.; Madureira, A.R.; Sarmento, B.; Gomes, A.; Pintado, M.E. Study of the interactions between rosmarinic acid and bovine milk whey protein $\alpha$-lactoalbumin, $\beta$-lactoglobulin and lactoferrin. Food Res. Int. 2015, 77, 450-459. [CrossRef]

66. Fang, Z.; Bhandari, B. Encapsulation of polyphenols-A review. Trends Food Sci. Technol. 2010, 21, 510-523. [CrossRef]

67. Lucas-Abellán, C.; Fortea, I.; López-Nicolás, J.M.; Núñez-Delicado, E. Cyclodextrins as resveratrol carrier system. Food Chem. 2007, 104, 39-44. [CrossRef]

68. Lucas-Abellán, C.; Fortea, I.; Gabaldón, J.A.; Núñez-Delicado, E. Encapsulation of quercetin and myricetin in cyclodextrins at acidic pH. J. Agric. Food Chem. 2007, 56, 255-259. [CrossRef] [PubMed]

69. Bhandari, B.R.; D'Arc, B.R.; Padukka, I. Encapsulation of lemon oil by paste method using $\beta$-cyclodextrin: Encapsulation efficiency and profile of oil volatiles. J. Agric. Food Chem. 1999, 47, 5194-5197. [CrossRef] [PubMed]

70. Ciobanu, A.; Mallard, I.; Landy, D.; Brabie, G.; Nistor, D.; Fourmentin, S. Inclusion interactions of cyclodextrins and crosslinked cyclodextrin polymers with linalool and camphor in lavandula angustifolia essential oil. Carbohydr. Polym. 2012, 87, 1963-1970. [CrossRef]

71. Haslam, E.; Lilley, T.H.; Butler, L.G. Natural astringency in foodstuffs-A molecular interpretation. Crit. Rev. Food Sci. Nutr. 1988, 27, 1-40. [CrossRef]

72. Chen, L.; Remondetto, G.E.; Subirade, M. Food protein-based materials as nutraceutical delivery systems. Trends Food Sci. Technol. 2006, 17, 272-283. [CrossRef]

73. Gouin, S. Microencapsulation. Trends Food Sci. Technol. 2004, 15, 330-347. [CrossRef]

74. Ezhilarasi, P.N.; Karthik, P.; Chhanwal, N.; Anandharamakrishnan, C. Nanoencapsulation techniques for food bioactive components: A review. Food Bioprocess Technol. 2013, 6, 628-647. [CrossRef]

75. Cheynier, V. Polyphenols in foods are more complex than often thought. Am. J. Clin. Nutr. 2005, 81, 223s-229s. [CrossRef] [PubMed] 
76. Li, H.; Zhao, X.; Ma, Y.; Zhai, G.; Li, L.; Lou, H. Enhancement of gastrointestinal absorption of quercetin by solid lipid nanoparticles. J. Control. Release 2009, 133, 238-244. [CrossRef] [PubMed]

77. Müller, R.H.; Mäder, K.; Gohla, S. Solid lipid nanoparticles (sln) for controlled drug delivery-A review of the state of the art. Eur. J. Pharm. Biopharm. 2000, 50, 161-177. [CrossRef]

78. Wenzel, E.; Somoza, V. Metabolism and bioavailability of trans-resveratrol. Mol. Nutr. Food Res. 2005, 49, 472-481. [CrossRef] [PubMed]

79. Yu, L.; Sun, Z.-J.; Wu, S.-L.; Pan, C.-E. Effect of resveratrol on cell cycle proteins in murine transplantable liver cancer. World J. Gastroenterol. 2003, 9, 2341. [CrossRef] [PubMed]

80. Sessa, M.; Tsao, R.; Liu, R.; Ferrari, G.; Donsì, F. Evaluation of the stability and antioxidant activity of nanoencapsulated resveratrol during in vitro digestion. J. Agric. Food Chem. 2011, 59, 12352-12360. [CrossRef] [PubMed]

81. Fang, J.-Y.; Hung, C.-F.; Liao, M.-H.; Chien, C.-C. A study of the formulation design of acoustically active lipospheres as carriers for drug delivery. Eur. J. Pharm. Biopharm. 2007, 67, 67-75. [CrossRef] [PubMed]

82. Shao, J.; Li, X.; Lu, X.; Jiang, C.; Hu, Y.; Li, Q.; You, Y.; Fu, Z. Enhanced growth inhibition effect of resveratrol incorporated into biodegradable nanoparticles against glioma cells is mediated by the induction of intracellular reactive oxygen species levels. Colloids Surf. B Biointerfaces 2009, 72, 40-47. [CrossRef] [PubMed]

83. Lu, X.; Ji, C.; Xu, H.; Li, X.; Ding, H.; Ye, M.; Zhu, Z.; Ding, D.; Jiang, X.; Ding, X. Resveratrol-loaded polymeric micelles protect cells from a $\beta$-induced oxidative stress. Int. J. Pharm. 2009, 375, 89-96. [CrossRef] [PubMed]

84. Teskač, K.; Kristl, J. The evidence for solid lipid nanoparticles mediated cell uptake of resveratrol. Int. J. Pharm. 2010, 390, 61-69. [CrossRef] [PubMed]

85. Zhou, H.; Sun, X.; Zhang, L.; Zhang, P.; Li, J.; Liu, Y.-N. Fabrication of biopolymeric complex coacervation core micelles for efficient tea polyphenol delivery via a green process. Langmuir 2012, 28, 14553-14561. [CrossRef] [PubMed]

86. Wang, Y.; Sukhishvili, S.A. All-aqueous nanoprecipitation: Spontaneous formation of hydrogen-bonded nanoparticles and nanocapsules mediated by phase separation of poly ( $N$-isopropylacrylamide). Macromol. Rapid Commun. 2017, 38, 1700242. [CrossRef] [PubMed]

87. Zhao, G.; Hu, C.; Sun, R.; Ni, S.; Li, Q.; Xia, Q. Development of novel composite antioxidant multiple lipid particles from combination of $\mathrm{w} / \mathrm{o} / \mathrm{w}$ multiple emulsions and solid lipid nanoparticles. Eur. J. Lipid Sci. Technol. 2015, 117, 1056-1065. [CrossRef]

88. Montes, A.; Wehner, L.; Pereyra, C.; Martínez de la Ossa, E.J. Precipitation of submicron particles of rutin using supercritical antisolvent process. J. Supercrit. Fluids 2016, 118, 1-10. [CrossRef]

89. Natolino, A.; Da Porto, C.; Rodríguez-Rojo, S.; Moreno, T.; Cocero, M.J. Supercritical antisolvent precipitation of polyphenols from grape marc extract. J. Supercrit. Fluids 2016, 118, 54-63. [CrossRef]

90. Markova, Z.; Novak, P.; Kaslik, J.; Plachtova, P.; Brazdova, M.; Jancula, D.; Siskova, K.M.; Machala, L.; Marsalek, B.; Zboril, R.; et al. Iron(II,III)-polyphenol complex nanoparticles derived from green tea with remarkable ecotoxicological impact. ACS Sustain. Chem. Eng. 2014, 2, 1674-1680. [CrossRef]

91. Liu, F.; Antoniou, J.; Li, Y.; Majeed, H.; Liang, R.; Ma, Y.; Ma, J.; Zhong, F. Chitosan/sulfobutylether$\beta$-cyclodextrin nanoparticles as a potential approach for tea polyphenol encapsulation. Food Hydrocoll. 2016, 57, 291-300. [CrossRef]

92. Chirio, D.; Gallarate, M.; Peira, E.; Battaglia, L.; Serpe, L.; Trotta, M. Formulation of curcumin-loaded solid lipid nanoparticles produced by fatty acids coacervation technique. J. Microencapsul. 2011, 28, 537-548. [CrossRef] [PubMed]

93. Sanguansri, P.; Augustin, M.A. Nanoscale materials development-A food industry perspective. Trends Food Sci. Technol. 2006, 17, 547-556. [CrossRef]

94. Zuidam, N.J.; Shimoni, E. Overview of microencapsulates for use in food products or processes and methods to make them. In Encapsulation Technologies for Active Food Ingredients and Food Processing; Springer: Berlin/Heidelberg, Germany, 2010; pp. 3-29.

95. Solans, C.; Izquierdo, P.; Nolla, J.; Azemar, N.; Garcia-Celma, M.J. Nano-emulsions. Curr. Opin. Colloid Interface Sci. 2005, 10, 102-110. [CrossRef]

96. Kunieda, H.; Fukui, Y.; Uchiyama, H.; Solans, C. Spontaneous formation of highly concentrated water-in-oil emulsions (gel-emulsions). Langmuir 1996, 12, 2136-2140. [CrossRef] 
97. Shinoda, K.; Saito, H. The effect of temperature on the phase equilibria and the types of dispersions of the ternary system composed of water, cyclohexane, and nonionic surfactant. J. Colloid Interface Sci. 1968, 26, 70-74. [CrossRef]

98. Zambaux, M.; Bonneaux, F.; Gref, R.; Maincent, P.; Dellacherie, E.; Alonso, M.; Labrude, P.; Vigneron, C. Influence of experimental parameters on the characteristics of poly (lactic acid) nanoparticles prepared by a double emulsion method. J. Control. Release 1998, 50, 31-40. [CrossRef]

99. Tice, T.R.; Gilley, R.M. Preparation of injectable controlled-release microcapsules by a solvent-evaporation process. J. Control. Release 1985, 2, 343-352. [CrossRef]

100. Aguiar, J.; Estevinho, B.N.; Santos, L. Microencapsulation of natural antioxidants for food application-The specific case of coffee antioxidants-A review. Trends Food Sci. Technol. 2016, 58, 21-39. [CrossRef]

101. Reverchon, E.; Della Porta, G.; Di Trolio, A.; Pace, S. Supercritical antisolvent precipitation of nanoparticles of superconductor precursors. Ind. Eng. Chem. Res. 1998, 37, 952-958. [CrossRef]

102. Jin, H.; Xia, F.; Jiang, C.; Zhao, Y.; He, L. Nanoencapsulation of lutein with hydroxypropylmethyl cellulose phthalate by supercritical antisolvent. Chin. J. Chem. Eng. 2009, 17, 672-677. [CrossRef]

103. Fessi, H.; Puisieux, F.; Devissaguet, J.P.; Ammoury, N.; Benita, S. Nanocapsule formation by interfacial polymer deposition following solvent displacement. Int. J. Pharm. 1989, 55, R1-R4. [CrossRef]

104. Bareras-Urbina, C.G.; Ramírez-Wong, B.; López-Ahumada, G.A.; Burruel-Ibarra, S.E.; Martínez-Cruz, O.; Tapia-Hernández, J.A.; Rodríguez Félix, F. Nano- and micro-particles by nanoprecipitation: Possible application in the food and agricultural industries. Int. J. Food Prop. 2016, 19, 1912-1923. [CrossRef]

105. Bilati, U.; Allémann, E.; Doelker, E. Development of a nanoprecipitation method intended for the entrapment of hydrophilic drugs into nanoparticles. Eur. J. Pharm. Sci. 2005, 24, 67-75. [CrossRef] [PubMed]

106. Shakeri, F.; Shakeri, S.; Hojjatoleslami, M. Preparation and characterization of carvacrol loaded polyhydroxybutyrate nanoparticles by nanoprecipitation and dialysis methods. J. Food Sci. 2014, 79, N697-N705. [CrossRef] [PubMed]

107. Mora-Huertas, C.E.; Garrigues, O.; Fessi, H.; Elaissari, A. Nanocapsules prepared via nanoprecipitation and emulsification-Diffusion methods: Comparative study. Eur. J. Pharm. Biopharm. 2012, 80, 235-239. [CrossRef] [PubMed]

108. Govender, T.; Stolnik, S.; Garnett, M.C.; Illum, L.; Davis, S.S. Plga nanoparticles prepared by nanoprecipitation: Drug loading and release studies of a water soluble drug. J. Control. Release 1999, 57, 171-185. [CrossRef]

109. Khan, S.A.; Schneider, M. Nanoprecipitation versus Two Step Desolvation Technique for the Preparation of Gelatin Nanoparticles; SPIE BiOS; International Society for Optics and Photonics: Bellingham, WA, USA, 2013; p. $85950 \mathrm{H}$.

110. Nakagawa, K.; Surassmo, S.; Min, S.-G.; Choi, M.-J. Dispersibility of freeze-dried poly (epsilon-caprolactone) nanocapsules stabilized by gelatin and the effect of freezing. J. Food Eng. 2011, 102, 177-188. [CrossRef]

111. Paramera, E.I.; Konteles, S.J.; Karathanos, V.T. Microencapsulation of curcumin in cells of saccharomyces cerevisiae. Food Chem. 2011, 125, 892-902. [CrossRef]

112. Yu, H.; Huang, Q. Bioavailability and delivery of nutraceuticals and functional foods using nanotechnology. Bio-Nanotechnol. Revolut. Food Biomed. Health Sci. 2013, 593-604. [CrossRef]

113. Fathi, M.; Martín, Á.; McClements, D.J. Nanoencapsulation of food ingredients using carbohydrate based delivery systems. Trends Food Sci. Technol. 2014, 39, 18-39. [CrossRef]

114. Sinha, V.; Kumria, R. Polysaccharides in colon-specific drug delivery. Int. J. Pharm. 2001, 224, 19-38. [CrossRef]

115. Qi, Z.; Xu, A. Starch-based ingredients for flavor encapsulation. Cereal Foods World 1999, 44, 460-465.

116. Pu, H.; Chen, L.; Li, X.; Xie, F.; Yu, L.; Li, L. An oral colon-targeting controlled release system based on resistant starch acetate: Synthetization, characterization, and preparation of film-coating pellets. J. Agric. Food Chem. 2011, 59, 5738-5745. [CrossRef] [PubMed]

117. George, M.; Abraham, T. pH sensitive alginate-guar gum hydrogel for the controlled delivery of protein drugs. Int. J. Pharm. 2007, 335, 123-129. [CrossRef] [PubMed]

118. Hu, B.; Pan, C.; Sun, Y.; Hou, Z.; Ye, H.; Zeng, X. Optimization of fabrication parameters to produce chitosan-Tripolyphosphate nanoparticles for delivery of tea catechins. J. Agric. Food Chem. 2008, 56, 7451-7458. [CrossRef] [PubMed] 
119. Konecsni, K.; Low, N.; Nickerson, M. Chitosan-tripolyphosphate submicron particles as the carrier of entrapped rutin. Food Chem. 2012, 134, 1775-1779. [CrossRef] [PubMed]

120. Ekambaram, P.; Sathali, A.A.H.; Priyanka, P. Solid Lipid Nanoparticles: A review. Sci. Rev. Chem. Commun. 2012, 2, 80-102.

121. Weiss, J.; Takhistov, P.; McClements, D.J. Functional materials in food nanotechnology. J. Food Sci. 2006, 71, R107-R116. [CrossRef]

122. Severino, P.; Andreani, T.; Macedo, A.S.; Fangueiro, J.F.; Santana, M.H.A.; Silva, A.M.; Souto, E.B. Current state-of-art and new trends on lipid nanoparticles (SLN and NLC) for oral drug delivery. J. Drug Deliv. 2011, 2012. [CrossRef] [PubMed]

123. Singh, S.; Dobhal, A.K.; Jain, A.; Pandit, J.K.; Chakraborty, S. Formulation and evaluation of solid lipid nanoparticles of a water soluble drug: Zidovudine. Chem. Pharm. Bull. 2010, 58, 650-655. [CrossRef] [PubMed]

124. Campos, D.A.; Madureira, A.R.; Gomes, A.M.; Sarmento, B.; Pintado, M.M. Optimization of the production of solid witepsol nanoparticles loaded with rosmarinic acid. Colloids Surf. B Biointerfaces 2014, 115, 109-117. [CrossRef] [PubMed]

125. Das, S.; Chaudhury, A. Recent advances in lipid nanoparticle formulations with solid matrix for oral drug delivery. AAPS Pharmscitech 2011, 12, 62-76. [CrossRef] [PubMed]

126. Nunes, S.; Madureira, A.R.; Campos, D.; Sarmento, B.; Gomes, A.M.; Pintado, M.; Reis, F. Solid lipid nanoparticles as oral delivery systems of phenolic compounds: Overcoming pharmacokinetic limitations for nutraceutical applications. Crit. Rev. Food Sci. Nutr. 2017, 57, 1863-1873. [CrossRef] [PubMed]

127. Campos, D.A.; Madureira, A.R.; Sarmento, B.; Gomes, A.M.; Pintado, M.M. Stability of bioactive solid lipid nanoparticles loaded with herbal extracts when exposed to simulated gastrointestinal tract conditions. Food Res. Int. 2015, 78, 131-140. [CrossRef] [PubMed]

128. McClements, D.J.; Rao, J. Food-grade nanoemulsions: formulation fabrication, properties performance, biological fate and potential toxicity. Crit. Rev. Food Sci. Nutr. 2011, 4, 285-330. [CrossRef] [PubMed]

129. McClements, D.J.; Decker, E.A.; Park, Y.; Weiss, J. Structural design principles for delivery of bioactive components in nutraceuticals and functional foods. Crit. Rev. Food Sci. Nutr. 2009, 49, 577-606. [CrossRef] [PubMed]

130. Sozer, N.; Kokini, J.L. Nanotechnology and its applications in the food sector. Trends Biotechnol. 2009, 27, 82-89. [CrossRef] [PubMed]

131. Quintanilla-Carvajal, M.X.; Camacho-Díaz, B.H.; Meraz-Torres, L.S.; Chanona-Pérez, J.J.; Alamilla-Beltrán, L.; Jimenéz-Aparicio, A.; Gutiérrez-López, G.F. Nanoencapsulation: A new trend in food engineering processing. Food Eng. Rev. 2010, 2, 39-50. [CrossRef]

132. Rai, R. Advances in Food Biotechnology; Wiley: Hoboken, NJ, USA, 2015.

133. Bakowska-Barczak, A.M.; Kolodziejczyk, P.P. Black currant polyphenols: Their storage stability and microencapsulation. Ind. Crops Prod. 2011, 34, 1301-1309. [CrossRef]

134. Rashidinejad, A.; Birch, E.J.; Everett, D.W. A novel functional full-fat hard cheese containing liposomal nanoencapsulated green tea catechins: Manufacture and recovery following simulated digestion. Food Funct. 2016, 7, 3283-3294. [CrossRef] [PubMed]

135. Bhushani, J.A.; Kurrey, N.K.; Anandharamakrishnan, C. Nanoencapsulation of green tea catechins by electrospraying technique and its effect on controlled release and in-vitro permeability. J. Food Eng. 2017, 199, 82-92. [CrossRef]

136. Pandita, D.; Kumar, S.; Poonia, N.; Lather, V. Solid lipid nanoparticles enhance oral bioavailability of resveratrol, a natural polyphenol. Food Res. Int. 2014, 62, 1165-1174. [CrossRef]

137. Kulandaivelu, K.; Mandal, A.K.A. Positive regulation of biochemical parameters by tea polyphenol encapsulated solid lipid nanoparticles at in vitro and in vivo conditions. IET Nanobiotechnol. 2016, 10, 419-424. [CrossRef] [PubMed]

138. Madureira, A.R.; Campos, D.A.; Oliveira, A.; Sarmento, B.; Pintado, M.M.; Gomes, A.M. Insights into the protective role of solid lipid nanoparticles on rosmarinic acid bioactivity during exposure to simulated gastrointestinal conditions. Colloids Surf. B Biointerfaces 2016, 139, 277-284. [CrossRef] [PubMed]

139. Fathi, M.; Varshosaz, J.; Mohebbi, M.; Shahidi, F. Hesperetin-loaded solid lipid nanoparticles and nanostructure lipid carriers for food fortification: Preparation, characterization, and modeling. Food Bioprocess Technol. 2013, 6, 1464-1475. [CrossRef] 
140. Fathi, M.; Varshosaz, J. Novel hesperetin loaded nanocarriers for food fortification: Production and characterization. J. Funct. Foods 2013, 5, 1382-1391. [CrossRef]

141. Augustin, M.A.; Hemar, Y. Nano-and micro-structured assemblies for encapsulation of food ingredients. Chem. Soc. Rev. 2009, 38, 902-912. [CrossRef] [PubMed]

142. Das, M.; Saxena, N.; Dwivedi, P.D. Emerging trends of nanoparticles application in food technology: Safety paradigms. Nanotoxicology 2009, 3, 10-18. [CrossRef]

143. Kreyling, W.; Semmler, M.; Erbe, F.; Mayer, P.; Takenaka, S.; Schulz, H.; Oberdörster, G.; Ziesenis, A. Translocation of ultrafine insoluble iridium particles from lung epithelium to extrapulmonary organs is size dependent but very low. J. Toxicol. Environ. Health Part A 2002, 65, 1513-1530. [CrossRef] [PubMed]

144. Bouwmeester, H.; Dekkers, S.; Noordam, M.Y.; Hagens, W.I.; Bulder, A.S.; de Heer, C.; ten Voorde, S.E.C.G.; Wijnhoven, S.W.P.; Marvin, H.J.P.; Sips, A.J.A.M. Review of health safety aspects of nanotechnologies in food production. Regul. Toxicol. Pharmacol. 2009, 53, 52-62. [CrossRef] [PubMed]

145. Aprahamian, M.; Michel, C.; Humbert, W.; Devissaguet, J.; Damge, C. Transmucosal passage of polyalkylcyanoacrylate nanocapsules as a new drug carrier in the small intestine. Biol. Cell 1987, 61, 69-76. [CrossRef] [PubMed]

146. Hoet, P.H.; Brüske-Hohlfeld, I.; Salata, O.V. Nanoparticles-Known and unknown health risks. J. Nanobiotechnol. 2004, 2, 12. [CrossRef] [PubMed]

147. Florence, A.T. Nanoparticle uptake by the oral route: Fulfilling its potential? Drug Discov. Today Technol. 2005, 2, 75-81. [CrossRef] [PubMed]

148. Szentkuti, L. Light microscopical observations on luminally administered dyes, dextrans, nanospheres and microspheres in the pre-epithelial mucus gel layer of the rat distal colon. J. Control. Release 1997, 46, $233-242$. [CrossRef]

149. Gabor, F.; Bogner, E.; Weissenboeck, A.; Wirth, M. The lectin-Cell interaction and its implications to intestinal lectin-mediated drug delivery. Adv. Drug Deliv. Rev. 2004, 56, 459-480. [CrossRef] [PubMed]

150. Dobrovolskaia, M.A.; McNeil, S.E. Immunological properties of engineered nanomaterials. Nat. Nanotechnol. 2007, 2, 469-478. [CrossRef] [PubMed]

151. Letchford, K.; Burt, H. A review of the formation and classification of amphiphilic block copolymer nanoparticulate structures: Micelles, nanospheres, nanocapsules and polymersomes. Eur. J. Pharm. Biopharm. 2007, 65, 259-269. [CrossRef] [PubMed]

152. Jani, P.; Halbert, G.W.; Langridge, J.; Florence, A.T. Nanoparticle uptake by the rat gastrointestinal mucosa: Quantitation and particle size dependency. J. Pharm. Pharmacol. 1990, 42, 821-826. [CrossRef] [PubMed]

153. De Jong, W.H.; Hagens, W.I.; Krystek, P.; Burger, M.C.; Sips, A.J.; Geertsma, R.E. Particle size-dependent organ distribution of gold nanoparticles after intravenous administration. Biomaterials 2008, 29, 1912-1919. [CrossRef] [PubMed]

154. Chau, C.-F.; Wu, S.-H.; Yen, G.-C. The development of regulations for food nanotechnology. Trends Food Sci. Technol. 2007, 18, 269-280. [CrossRef]

155. Madureira, A.R.; Nunes, S.; Campos, D.A.; Fernandes, J.C.; Marques, C.; Zuzarte, M.; Gullón, B.; Rodríguez-Alcalá, L.M.; Calhau, C.; Sarmento, B. Safety profile of solid lipid nanoparticles loaded with rosmarinic acid for oral use: In vitro and animal approaches. Int. J. Nanomed. 2016, 11, 3621-3640.

(C) 2018 by the authors. Licensee MDPI, Basel, Switzerland. This article is an open access article distributed under the terms and conditions of the Creative Commons Attribution (CC BY) license (http://creativecommons.org/licenses/by/4.0/). 